\title{
Mucosal and skin HPV types in tumour-free tonsils and tonsillar tumours
}

\author{
M. SALAKOVA ${ }^{1, *}$, E. KOSLABOVA², M. GREGA ${ }^{3}$, J. SMAHELOVA ${ }^{1}$, J. KLOZAR ${ }^{2}$, O. VENCALEK ${ }^{4}$, R. TACHEZY ${ }^{1}$ \\ ${ }^{1}$ Department of Genetics and Microbiology, Faculty of Science, Charles University, Prague, Czech Republic; ${ }^{2}$ Department of Otorhinolaryngology \\ and Head and Neck Surgery, $1^{\text {st }}$ Faculty of Medicine, Charles University, Motol University Hospital, Prague, Czech Republic; ${ }^{3}$ Department of \\ Pathology and Molecular Medicine, $2^{\text {nd }}$ Faculty of Medicine, Charles University, Prague, Czech Republic; ${ }^{4}$ Department of Mathematical Analysis \\ and Applications of Mathematics, Faculty of Science of the Palacky University in Olomouc, Czech Republic
}

*Correspondence: martina.salakova@natur.cuni.cz

Received March 14, 2017/ Accepted June 9, 2017

Human papillomavirus (HPV) infection is associated with tonsillar cancer (TC) whose incidence in humans is increasing. Tonsillar tumours are not ordinarily preceded by clinically apparent precancerous lesions, and no markers of the early stage disease are available. Therefore, we evaluated the presence of an active HPV infection also in tumour-free tonsillar tissue. Formalin-fixed paraffin-embedded (FFPE) tonsillar specimens from 114 patients with TC and 114 age and gender matched controls were screened for the presence of HPV DNA, expression of HR-HPV E6 mRNA, and p16 overexpression. HPV DNA was identified in 3.5\% of tumour-free tissues, HR-HPV16 and 58 and LR-HPV111 and 17 were each detected in a single sample. No HR HPV E6 mRNA and p16 overexpression was found. The prevalence of HPV DNA in TC was 69.3\%, with HPV16 being the most common (94.9\%). Eighty-four percent of HPV16-positive tumours expressed HR HPV E6 mRNA, while no E6 mRNA was present in samples positive for HPV52 and 58. The overexpression of p16 correlated well with HPV DNA in TC, but in tumour-free tonsils no overexpression of p16 was detected.

Our data provide further evidence of the etiological role of HPV16 in TC. In tumour-free tissue, the presence of HR-HPVs was rare and silent, as shown by direct and indirect markers.

Key words: human papillomavirus, tonsillar cancer, tumour-free tonsils, active infection

Papillomaviruses (PVs) are small DNA viruses which infect the skin and mucosal epithelium. They cause benign lesions as well as cancers of the urogenital tract in women and men and a part of the oropharyngeal tumours. Fortunately, most human papillomavirus (HPV) infections are asymptomatic [1]. In the last decade, it has been shown that oropharyngeal tumours whose incidence is steadily increasing are etiologically linked with infection by highrisk (HR) alpha-PVs [2-4]. Patients with HPV-associated tumours have better prognosis and five-year survival [5]. In other locations of head and neck cancer (HNC), the involvement of HPVs is not clear.

Alpha-PV types have been detected in approximately $4.5 \%$ to $12 \%$ of oral samples from healthy individuals, and their prevalence seems to increase with age [6-8]. In patients with oropharyngeal tumours, a very good correlation of the type specific presence of alpha-PVs has been found between tumour tissues and oral rinses, suggesting that cells containing the virus are shed from the tumour [9-11]. Cutaneous HPV types are also frequently detected in the oral cavity [12-14], but information on the prevalence of cutaneous types in
HNCs is inconsistent, and its clinical importance remains unknown $[15,16]$. We have recently shown that more than $55 \%$ of oral and $46 \%$ of oropharyngeal tumours contain beta-PVs, and the tissues are often co-infected with multiple types of HPV [14].

Cervical cancer is preceded by precancerous lesions, and screening programs based on the HPV detection to identify women at risk have been successfully introduced worldwide. Tonsillar tumours are not ordinarily preceded by any clinically apparent precancerous lesions, and no markers of the early stage disease are available so far. Therefore, no screening programs for oropharyngeal cancer exist. Surprisingly, just recently, it has been shown that antibodies specific for HPV oncogenes can be detected years prior to oropharyngeal cancer diagnosis [17]. This finding certainly needs confirmation in larger studies, but can be suggestive of the presence of precancerous lesions hidden in the tonsillar crypts. However, a recent study which aimed to evaluate deep brushing of tonsillar crypts with liquid based cytology and HPV testing for the detection of precancerous lesions has failed to detect any lesion [18]. The limited number of 
studies on the prevalence of HPV in healthy tonsillar tissue in a negligible number of analysed samples have suggested that the HPV presence is rare [19-23]. A recently published large study from the UK has found no HPV infection in tumour-free tonsil tissue from 4,095 subjects aged 0-69 years whose paired tonsils were archived after tonsillectomy [24].

The importance of detecting active viral infection in tonsillar tumours has been shown, but no study has been published which aims to detect viral mRNA in tumour-free tonsils, and only one study has evaluated the presence of an indirect marker of an active viral infection, p16, in tumourfree tonsils [25]. In the present study, we aim to compare the prevalence of active HPV infection by alpha- and beta-PVs in tonsillar tumour tissues and tumour-free tonsillar tissues of age and sex matched group of patients.

\section{Patients and methods}

Study population. Altogether 228 patients were included in the study, i.e. 114 patients with tonsillar carcinoma (TC) and 114 subjects with tumour-free tonsillar tissues. All patients with primary squamous cell TC (ICD-10: C090-C099) were treated in the Department of Otorhinolaryngology and Head and Neck Surgery in the period of 2001-2007. A subset of 45 TC patients have been tested for the presence of active viral infection by mucosal alpha-PV types as well as for the expression of $\mathrm{p} 16$ and $\mathrm{p} 53$ proteins in our previous study [5]. Here, their samples were additionally tested for the presence of skin PV types. The patients with tumour-free tonsils suffered from chronic tonsillitis, peritonsillar abscess, or sleep apnoea syndrome and were admitted for tonsillectomy. The study received official institutional and ethical approval from the participating institutions. Data on demographics, risk factors for oral cavity and oropharyngeal cancer, and risks related to HPV exposure were collected by a questionnaire. In some patients with tumour-free tonsils (92), only smoking status was known. The medical records and pathology reports were reviewed for each subject.

Tissue specimens. From oropharyngeal cancer (OPC) patients, tumour biopsy specimens were collected as described in detail previously [11]. From each paraffin block, the first and last sections were histologically analysed to confirm that the sections in between - assigned for the detection of viral nucleic acids and immunohistochemical (IHC) analysis - contained at least $10 \%$ of tumour cells in the entire volume of the sample. Carcinoma-free tonsillar tissue was fixed in $10 \%$ neutral formalin and paraffin embedded, and sections were taken for histological, imunohistochemical, and molecular biological analysis. During sample processing, stringent precautions were taken to avoid cross-contamination between samples. The microtome was cleaned carefully, and the blade was replaced for the sectioning of each tissue.

In all tumour-free tonsillar tissues and 93 tonsillar carcinoma tissues, simultaneous DNA and RNA extraction was performed from two $20 \mu \mathrm{m}$ sections using the Ambion ${ }^{\circ}$
RecoverAll $^{\mathrm{TM}}$ Total Nucleic Acid Isolation Kit for FFPE Tissues according to the manufacturer's protocol (Applied Bioscience, Austin, TX). The remaining 21 samples from patients with tonsillar carcinoma were available only for DNA extraction.

PCR. As an internal control, a $110 \mathrm{bp}$ fragment of the human beta-globin gene was amplified as described previously [26]. HPV DNA detection was performed by PCR with broad spectrum primers specific for the L1 region, and HPV typing was done by reverse line blot hybridization with probes specific for 37 types. All methods have been previously described in detail [27].

Tonsillar tissues were additionally analysed for HPV DNA by modified nested PCR with two degenerated primer pairs: FAP59/64 in the first step and FAP6085F/FAP6319R in the second step. These PCR assays were designed to amplify conserved regions of the L1 gene with generated amplicon sizes of $480 \mathrm{bp}$ in the first PCR reaction and $235 \mathrm{bp}$ in the second PCR reaction $[28,29]$. Nucleotide DNA sequences of the FAP6085F/FAP6319R PCR products were determined using the ABI Big Dye Sequencing kit (Applied Biosystems, Foster City, CA). The sequencing was performed on an ABI PRISM 3500 automated DNA sequencer (Applied Biosystems, Foster City, CA).

cDNA was prepared by reverse transcription of $1 \mu \mathrm{g}$ of RNA initially treated with RNase-Free DNase (Promega, WI), followed by reverse transcription with M-MLV reverse transcriptase (Promega, WI). The absence of contaminating DNA was confirmed by the absence of amplification of the internal control (human beta-globin gene) on RNA treated with DNase.

PCR specific for HPV16 E6 ${ }^{\star} I$ mRNA oncoprotein was performed on cDNA with primers that amplify an 86-nt fragment [30]. These primers can distinguish between the splice form of HPV16 E6 mRNA with an 86-nt fragment and non-spliced contaminated DNA with 182 bp long fragments. For the detection of HPV52 and HPV58 E6 mRNA, we used the PCR assays with the primers described by Nakagawa [31]. The quality of cDNA was checked by control PCR with beta-globin primers.

Immunohistochemical analysis. IHC examination was performed on $2 \mu \mathrm{m}$ sections of FFPE tissue with the following antibodies: p16INK4a (Purified Mouse Anti-Human p16, Clone G175-405, BD PharmingenTM, dilution 1:100) and p53 (Monoclonal Mouse Anti-Human p53 Protein, Clone DO-7, Dako, dilution 1:50). The intensity of staining (graded + to +++ ) and the proportion of cells stained (scored in percentages) were evaluated. For p16 immunostaining, the location of the signal (cytoplasmic and/or nuclear) was also specified. A semi-quantitative evaluation was performed. The sample positive for p16 expression had to show more than $70 \%$ of positive cells and reveal nuclear and/or cytoplasmic staining.

Statistical analysis. For contingency tables, the standard chi-square test and the Fisher exact test were used. The Kappa statistic was used to measure agreement for HPV 
positivity status and p16 and p53 overexpression. All tests were two sided with a significance level of $\mathrm{a}=0.05$. The Cox proportional hazards model was used for the analysis of disease specific survival (DSS) and overall survival (OS). The Akaike information criterion (AIC) was applied for model selection. The following demographic and clinical pathological factors were included: gender, age, education (12 years, $>12$ years), smoking status (non-smoker; smoker), alcohol status (non-drinker; drinker), tumour size $(\mathrm{T}=1+2 ; \mathrm{T}=3+4)$, nodal status (negative $\mathrm{N}=0$; positive $\mathrm{N} 1-\mathrm{N} 3$ ), tumour stage $(\mathrm{I}+\mathrm{II}, \mathrm{III}+\mathrm{IV})$, histological tumour grade $(\mathrm{G}=1 ; \mathrm{G}>1)$, and HPV status (HPV DNA positive; p16 positive, positive for both HPV DNA and p16). Statistics were generated using the GraphPad InStat 3.00 software (GraphPad Software, San Diego, CA) and SAS 9.1 software (SAS System for Windows. Version 8.2., Cary, NC:SAS Institute; 2001).

\section{Results}

Demographic and clinical pathological characteristics. In the two study groups, one with tumour-free tonsils and the other with tonsillar carcinoma, there were $81.6 \%$ men (93/114) and $18.4 \%$ women (21/114) (Table 1). The mean age was 55 years in the group with tumour-free tonsils and 56 years in the group of cancer patients. The demographic characteristics of the study subjects are summarized in Table 1 . The majority of controls $(71.7 \% ; 66 / 92)$ were non-smokers. In the group of patients with tonsillar carcinoma, $62.3 \%$ (71/114) were non-smokers, but most patients $(74.6 \% ; 85 / 114)$ drank alcohol. The cancer patients had more frequently smaller tumours $(\mathrm{T} 1+2$ vs $\mathrm{T} 3+4 ; 79.0 \%$ and $21.0 \%$, respectively). HPV DNA-positive lymph nodes were found in the majority of cases (N0 vs N1-3, 24.6\% and $75.4 \%$ ). The tumours had higher tumour stages (I, II vs III, IV, $23.7 \%$ and $76.3 \%$, respectively) and were also more commonly well and moderately differentiated (G1 + 2 vs G3, $61.1 \%$ and $38.9 \%$, respectively).

HPV DNA detection. Out of 114 patients with tumourfree tonsils, $3.5 \%$ (4/114) were HPV DNA positive. HR-HPV16 and HPV58 from the alpha-PV 9 group were found in one tonsil each, and in two additional tonsils, low-risk (LR) HPV17 and HPV111 from the beta-PV 2 group were revealed again in one tonsil each. The two HR-HPV types were detected by PCR with primers BSGP5+/6+bio and reverse line blot hybridization; therefore, multiple infections could be ruled out, while the beta-PVs were detected by PCR with FAP primers and sequencing, which only allows the detection of the most prevalent type in the sample.

Of 114 patients with tonsillar tumours, 67.5\% (77/114) were positive for HR-HPV. HPV16 was the most common

Table 1. Demographic and clinical characteristics of study subjects.

\begin{tabular}{|c|c|c|c|c|c|c|c|}
\hline & Characteristics & & $\begin{array}{l}\text { Total } \\
\text { N (\%) }\end{array}$ & $\begin{array}{c}\text { HR HPV+ cases } \\
\text { N (\%) }\end{array}$ & $\begin{array}{c}\text { HR HPV- cases } \\
\text { N (\%) }\end{array}$ & $\begin{array}{c}\text { OR } \\
(95 \% \mathrm{CI})\end{array}$ & p-value \\
\hline \multirow[t]{6}{*}{ Patients with tumour-free tonsils } & Age & $\leq 55$ & $63(55.3)$ & $1(1.6)$ & $62(98.4)$ & $0.806(0.049-13.2)$ & 1.0 \\
\hline & & $>55$ & $51(44.7)$ & $1(2.0)$ & $50(98.0)$ & & \\
\hline & Gender & Female & $21(18.4)$ & $0(0.0)$ & $21(100.0)$ & $0.851(0.039-18.4)$ & 1.0 \\
\hline & & Male & $93(81.6)$ & $2(2.1)$ & $91(97.9)$ & & \\
\hline & Smoking status ${ }^{\mathrm{a}}$ & Smoker & $66(71.3)$ & $0(0.0)$ & $66(100.0)$ & $0.453(0.187-1.09)$ & 0.3093 \\
\hline & & Non-smoker & $26(28.3)$ & $2(7.7)$ & $24(92.3)$ & & \\
\hline \multirow[t]{18}{*}{ Patients with tonsillar carcinoma } & Age & $\leq 55$ & $51(44.7)$ & $29(56.9)$ & $22(43.1)$ & $0.412(0.185-0.912)$ & 0.436 \\
\hline & & $>55$ & $63(55.3)$ & $48(76.2)$ & $15(23.8)$ & & \\
\hline & Gender & Female & $21(18.4)$ & $17(80.9)$ & $4(19.1)$ & $2.34(0.726-7.527)$ & 0.199 \\
\hline & & Male & $93(81.6)$ & $60(65.5)$ & $33(35.5)$ & & \\
\hline & Education & $\leq 12$ & $70(63.1)$ & $45(64.3)$ & $25(35.7)$ & $0.660(0.283-1.539)$ & 0.403 \\
\hline & & $>12$ & $41(36.9)$ & $30(73.2)$ & $11(26.8)$ & & \\
\hline & Tobacco status & No & $71(62.3)$ & $57(80.3)$ & $14(19.7)$ & $4.682(2.027-10.82)$ & $0.0004^{*}$ \\
\hline & & Yes & $43(37.7)$ & $20(46.5)$ & $23(53.5)$ & & \\
\hline & Alcohol status & Non-drinker & $29(25.4)$ & $24(82.8)$ & $5(17.2)$ & $2.898(1.005-8.356)$ & 0.065 \\
\hline & & Drinker & $85(74.6)$ & $53(62.4)$ & $32(37.6)$ & & \\
\hline & Tumour size & $\mathrm{T} 1+\mathrm{T} 2$ & $90(79.0)$ & $62(68.9)$ & $26(28.8)$ & $1.431(0.556-3.681)$ & 0.466 \\
\hline & & $\mathrm{T} 3+\mathrm{T} 4$ & $24(21.0)$ & $15(62.5)$ & $9(37.5)$ & & \\
\hline & Nodal status & No & $28(24.6)$ & $14(50.0)$ & $14(50.0)$ & $0.365(0.151-0.882)$ & $0.0353^{*}$ \\
\hline & & N1-N3 & $86(75.4)$ & $63(73.3)$ & $23(26.7)$ & & \\
\hline & Stage & $\mathrm{I}+\mathrm{II}$ & $27(23.7)$ & $13(48.1)$ & $14(51.9)$ & $0.334(0.137-0.815)$ & $0.0188^{*}$ \\
\hline & & III+IV & $87(76.3)$ & $64(73.6)$ & $23(26.4)$ & & \\
\hline & Grade & $\mathrm{G} 1+\mathrm{G} 2$ & $69(61.1)$ & $42(60.9)$ & $27(39.1)$ & $0.400(0.166-0.962)$ & $0.0412^{*}$ \\
\hline & & G3 & $44(38.9)$ & $35(79.5)$ & $9(20.5)$ & & \\
\hline
\end{tabular}

* statistically significant $\mathrm{p}<0.05$; ; The smoking status was not known in 22 patients with tumour-free tonsils 
type, detected in $94.8 \%$ of HPV-positive samples (73/77). Additionally, HPV types 18, 26, 52, and 58 were found in one sample each (1.3\%, Table 2$)$. FAP PCR did not detect any additional HPV type in the tonsillar cancer tissues.

Demographic and clinical pathological characteristics of subjects with HPV-positive and HPV-negative tissues. In subjects with tumour-free tonsillar tissues, no statistical difference in smoking status and age was observed between HPV-positive and HPV-negative patients $(\mathrm{p}=0.3093$ and $\mathrm{p}=1$, respectively, Table 1 ).

There was no statistically significant difference between HPV-positive and HPV-negative TC patients in their age, gender, or education level. However, TC patients with HPV-positive and HPV-negative tumours differed significantly in smoking status, with the former being more often non-smokers $(\mathrm{p}=0.0004)$, while no difference was observed for alcohol status.

Additionally, no difference in tumour size was found between HPV-positive and HPV-negative TC patients. Regional lymph node metastasis was significantly more frequent in HR-HPV-positive patients $(\mathrm{p}=0.0353)$, and, consequently, the HPV-positive tumours were of higher stage (III and IV vs. I and II) ( $\mathrm{p}=0.0188)$. HPV-positive tumours were more often of higher grade (G1 and G2 vs G3) $(\mathrm{p}=0.0412)$.

Detection of markers of active viral infection. Ninetythree tonsillar carcinoma samples were available for RNA extraction. Two samples yielded no control beta-globin amplicon and were excluded from further analyses. Fiftythree $(86.9 \%)$ of 61 HPV16 DNA-positive tonsillar carcinoma samples were also HPV16 mRNA positive (Table 2). In any of 24 HPV16 DNA-negative samples, no HPV16 E6 mRNA was present. One sample positive for HR-HPV52 and another one positive for HR-HPV58 were available for mRNA testing. In these samples, no HPV E6 mRNA expression was detected. Tonsillar carcinoma samples positive for HPV18 and HPV26 DNA were not available for RNA expression analysis. In tumour-free tonsillar samples positive for HPV16 and HPV58 DNA, no HPV E6 mRNA transcript was found.

Overexpression of p16 was detected in 65.8\% (75/114) of tonsillar tumours, whereas p53 was expressed in $22.1 \%$ $(25 / 113)$ of such tumours. The status of p53 expression was not known for one sample. The p16 protein was expressed in all but eight (89.6\%) of HR-HPV DNA-positive TCs, six of which were HPV16 DNA positive. In the HR-HPV26 and 18 positive TCs, the 16 protein was overexpressed, in contrast to HR-HPV52 and 58 positive samples where no p16 expression was observed. In the HPV16 mRNA positive tonsillar cancer samples, p16 overexpression was found significantly more often than in mRNA-negative HPV16 DNA-positive samples $(\mathrm{p}=0.0136)$. Eight HPV DNA-positive cases $(10.5 \%$, $8 / 77$ ) were positive for $\mathrm{p} 53$ expression, and four of them simultaneously expressed p16 protein, whereas 45.9\% (17/37) HPV DNA-negative cases expressed p53, and only two did so along with p16 protein.
Table 2. HPV types, HR-HPV mRNA positivity, p16 and p53 overexpression in tonsillar tumours and tumour-free tonsillar tissues.

\begin{tabular}{llcc}
\hline Characteristics & & $\begin{array}{c}\text { Patients with } \\
\text { tonsillar } \\
\text { carcinoma } \\
+/ \mathbf{N}(\%)\end{array}$ & $\begin{array}{c}\text { Patients with } \\
\text { tumour-free } \\
\text { tonsils } \\
+/ \mathrm{N}(\%)\end{array}$ \\
\hline HPV & & $77 / 114(67.5)$ & $4 / 114(3.5)$ \\
HR-HPV & & $77 / 114(67.5)$ & $2 / 114(1.8)$ \\
& HPV16 $(\alpha 9)$ & $73 / 114(64.0)$ & $1 / 114(0.9)$ \\
& HPV18 $(\alpha 7)$ & $1 / 114(0.9)$ & \\
& HPV26 $(\alpha 5)$ & $1 / 114(0.9)$ & \\
& HPV52 $(\alpha 9)$ & $1 / 114(0.9)$ & $1 / 114(0.9)$ \\
LR-HPV & HPV58 $(\alpha 9)$ & $1 / 114(0.9)$ & $2 / 114(1.8)$ \\
& & & $1 / 114(0.9)$ \\
HPV16 E6 mRNA & HPV17 $(\beta 2)$ & & $1 / 114(0.9)$ \\
HPV52/58 E6 mRNA & & & $0 / 1^{\mathrm{a}}(0)$ \\
p16+ & & $53 / 61^{\mathrm{a}}(86.9)$ & $0 / 1^{\mathrm{b}}(0)$ \\
p53 & & $0 / 2^{\mathrm{b}}(0)$ & $0 / 114(0)$ \\
HR-HPV/p16+ & & $75 / 114(65.8)$ & $0 / 114(0)$ \\
HR-HPV/p53 & & $25 / 113(22.1)$ & \\
HR-HPV mRNA & & $69 / 114(60.5)$ & \\
\hline
\end{tabular}

a number of HPV16 DNA-positive samples

${ }^{\mathrm{b}}$ number of HPV52 or 58 DNA-positive samples

c number of TC samples with available RNA

A good correlation of the positivity of direct and indirect markers in tonsillar tumors was found for HPV16 mRNA presence and $\mathrm{p} 16$ overexpression $(\mathrm{k}=0.79)$, but no correlation was observed for HPV16 mRNA and p53 expression $(\mathrm{k}=-0.30)$. A good correlation was also established between HR-HPV DNA positivity and p16 presence $(\mathrm{k}=0.72)$, but no correlation was evident between HR-HPVDNA and p53 detection $(\mathrm{k}=-0.26)$.

The expression of p16 and p53 was negative in 100\% (114/114) of the tumour-free tonsillar tissues, including those positive for HR-HPVs (Table 2).

Survival of patients with tonsillar tumours. The overall as well as the disease-specific survival rates of patients with an active HPV infection (HPV DNA positive and p16 positive) were significantly higher than those of HPV DNA-negative patients or patients positive for either HPV DNA or p16 expression alone (OS $\mathrm{p}=0.001$; DSS $\mathrm{p}=0.009$ ). Additionally, the presence of regional lymph node metastasis and smoking negatively influenced the patients' survival (lymph nodes positivity OS $p=0.002$; DSS $p=0.047$; smoking OS $p=0.033$; DSS $\mathrm{p}=0.048$, Figure 1 ).

\section{Discussion}

The palatine tonsils are secondary lymphoid organs containing epithelial squamous cells and lymphoid and plasma cells. Tonsillar carcinoma which is strongly associated with HR-HPV infection originates primarily from the 

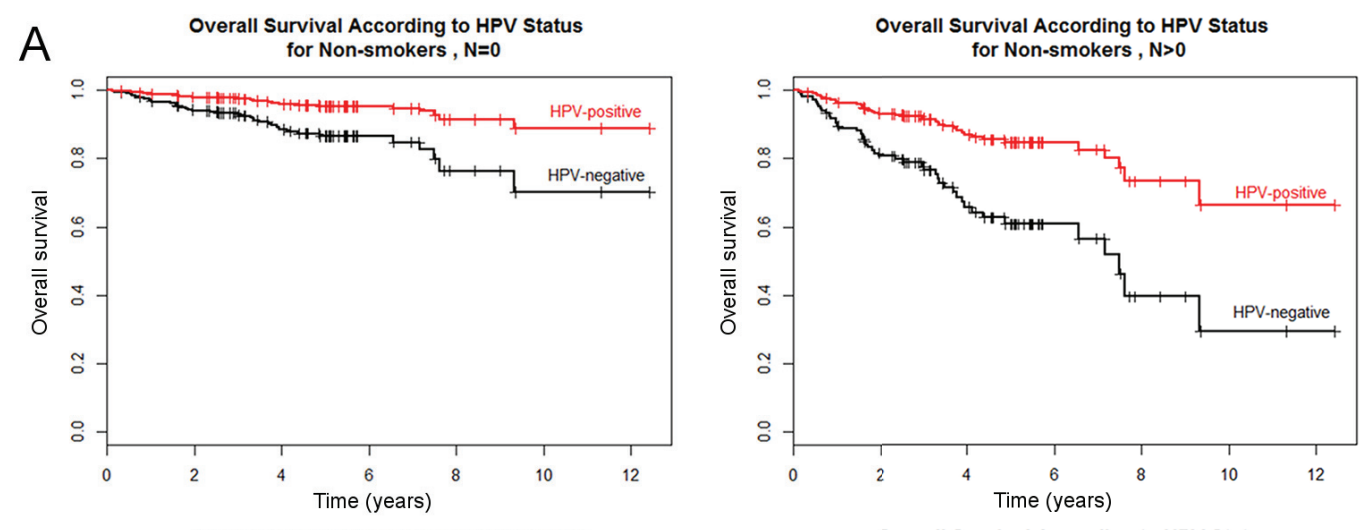

Overall Survival According to HPV Status

Overall Survival According to HPV Status
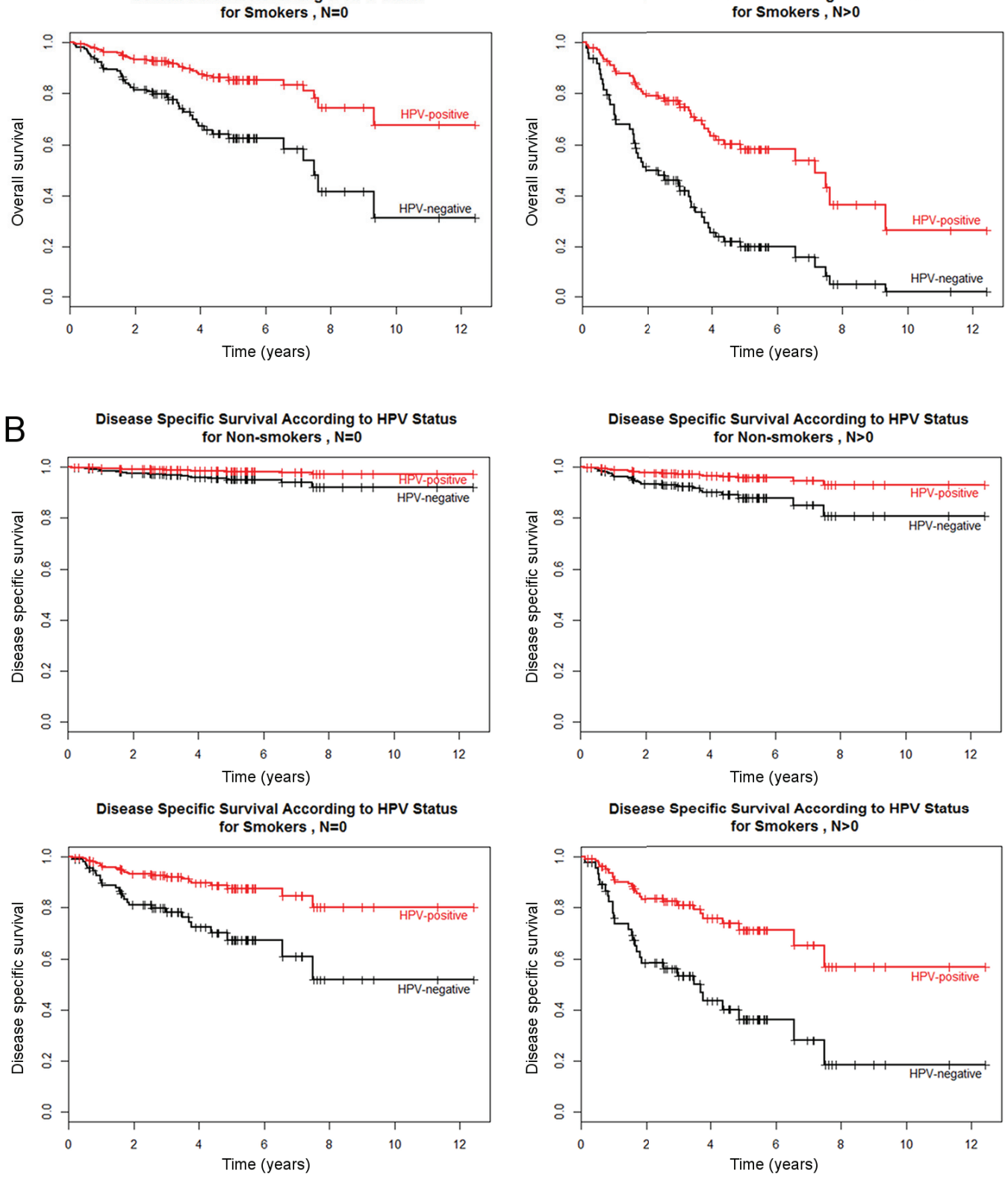

Figure 1. A/ Overall survival by HPV status, positivity of lymph nodes in smokers and non-smokers; B/ Disease-specific survival by HPV status, positivity of lymph nodes in smokers and non-smokers. Survival curves according to the Cox model. 
reticulated epithelial cells of the tonsillar crypts [32]. HPV was detected in $65 \%$ of tonsillar carcinoma patients in the Czech Republic between 2001 and 2007 [5]. During this period, the incidence of TC increased by $41 \%$ according to the Czech National Oncology Registry. The proportion of $\mathrm{HPV}$-associated tonsillar carcinomas is on the rise due to the increasing prevalence of sexually transmitted HPV infection caused by changes in human sexual behaviour [33]. It would be therefore very desirable to be able to identify the individuals at risk. Several studies including ours have shown that good correlation of the presence of HR-HPVs in tumour tissues and oral rinses suggests the presence of the virus in cells shed from the lesions $[9,34,10]$. However, there is a lack of evidence that the tumours of tonsils are preceded by the gradual development of precancerous lesions. In a limited number of studies, no precancerous lesions have been detected in healthy subjects despite HPV presence in oral rinses [6].

The prevalence of HPV in tonsillar carcinoma in our study was $67.5 \%$, which is in agreement with our previous data [5] as well as with other studies (reviewed in [35]). Only HR alpha-PV types were detected in our tumour samples. The most common type was HPV16. Other HPV types were found only rarely. No beta-PV type was revealed by FAP nested PCR in our study. Other studies have also failed to detect LR alpha-PV or beta-PV types in the tumour tissues $[36,15,22]$. However, using a highly sensitive type-specific bead-based multiplex genotyping assay [37-39], we have recently observed high prevalence rates of beta-PV types in oropharyngeal and oral tumours $(45.7 \%$ and $55.2 \%$, respectively) [14]. The two groups of HPV-negative and HPV-positive TC patients in our study were similar in terms of most demographic characteristics; however, there was a higher proportion of smokers in the group of HPV-negative patients with tonsillar carcinoma. This observation is in line with our previous results $[5,11]$. The overall and the diseasespecific survival analysis of the entire cohort showed that HPV positivity of the tumour is the strongest predictor of survival in TC. Interestingly, smoking negatively influences survival in both the HPV-positive and HPV-negative groups of patients.

Unlike tonsillar cancer samples, tumour-free tonsillar tissues exhibited a very low HPV prevalence of 3.5\%. In two samples of tumour-free tonsils only, we detected HR-HPV types 16 and 58, and two samples were positive for beta-PV types 17 and 111 using the FAP PCR system. So far, few small studies have found HR-HPVs in archived paraffin-embedded palatine tonsillar tissues. The positivity rates for HR-HPV types in these studies varied from $0 \%$ to $8.5 \%$ [19-23]. The HR-HPV-positive healthy tonsils were most frequently detected in children and adults under 25 years of age. Our tumour-free population was older (age matched to patients with TC), and the HPV prevalence was low. A recent large population-based study from the UK has found no HR-HPVpositive tonsils in the population [24], while LR-HPVs have been detected in $0-2 \%[20,22]$.
The PCR FAP system detects a broader spectrum of HPV types, preferentially beta- and gamma-PV types. HPVs of the beta papillomavirus genus are often detected in skin cancers among patients with epidermodysplasia verruciformis, but are also ubiquitously present on the skin of healthy subjects. Beta-PV types are widespread in the oral cavity of HIV-positive patients and healthy subjects $[12,13]$, but no direct proof of association of beta-PVs with the pathology in the oral region has been found so far. However, in recent studies, HPV5, HPV 122, and gamma-11- and gamma12-HPV have been found significantly associated with head and neck tumours [40, 14]. Additionally, Viarisio et al. [41] have highlighted some functional similarities between mucosal HR HPV types such as HPV16 and beta-3 HPV49. Beta-3 HPV types appear to be more abundant in the nasal cavity than on the skin.

The detection of HPV DNA itself is not sufficient to prove a causal association of HPV with the tumour. The detection of HPV E6 and/or E7 mRNA, the direct marker of an active HPV infection, may differentiate between the potentially oncogenic active infection and a transitory one [42]. The majority (84\%) of the HPV16 DNA-positive tonsillar carcinoma samples in our study harboured viral E6 mRNA. In our previous studies, we have detected HPV16 E6 mRNA in 94\% and $87 \%$ of the HPV16 DNA-positive samples of tonsillar tumours in a small specimen set $(\mathrm{N}=45)$ and a larger one $(\mathrm{N}=186)$, respectively $[5,43]$. The other HR-HPV-positive tonsillar cancers did not express viral E6 transcripts. The absence of mRNA in non-HPV16 HR-HPV-positive tonsillar carcinomas raises the question of the role of these HR-HPV types in OPC carcinogenesis. However, in cervical carcinoma tissues harbouring other HR-HPV types, viral transcripts specific for the respective HPV types have been found in all samples tested [44].

Moreover, no HR-HPV E6 mRNA was detected in our HR-HPV DNA-positive tumour-free samples. It implies that the infection is also transcriptionally silent. This conclusion is further supported by the absence of expression of the indirect marker of active viral infection - p16 protein.

Even if E6/E7 mRNA detection is accepted as the goldstandard test to prove the causal association of HR-HPV with the cancer, it is important to mention that this method is not suitable for use in routine practice because of the risk of RNA degradation. Therefore, other indirect markers of active HPV infection were tested. The use of immunohistochemical techniques to detect p16 followed by HPV DNA detection is accepted as a very reliable indirect approach to elucidate the transforming activity of HPV in oropharyngeal cancer [45]. However, p16 overexpression has also been detected in a proportion of non-transformed cells of the tonsillar crypt epithelium [32, 25]. Secondly, p16 overexpression does not occur exclusively in HPV-induced OPCs but also in a small proportion of HPV-negative head and neck squamous cell carcinomas (HNSCCs). In this study, 90\% of HR-HPV DNA-positive tonsillar carcinomas but 
also $14 \%$ of HR-HPV-negative tumours turned out to be positive for p16 protein. No p16 was detected in tumourfree tonsillar tissues. HPV52 and HPV58 DNA-positive TC tissues with no E6 mRNA expression also failed to show p16 overexpression. One study has reported mRNA detection in one TC positive for HPV58. The sample has been positive for both E6 mRNA and overexpression of cellular protein p16 [46]. We further assessed the p53 protein which should be expressed more often in HPV-negative tumours. As in our previous studies and those of others, the specificity and sensitivity of this marker for the evaluation of the non-HPV-associated tonsillar tumours was very low [5, 11]. This can be explained by the fact that the IHC analysis does not precisely reflect the p53 gene mutational status [47]. None of the tumour-free tissues was positive for $\mathrm{p} 53$ expression.

In our previous studies, the combination of serological detection of HPV-specific antibodies and HPV DNA in oral rinses had a high sensitivity and specificity for the selection of patients with HPV-associated tumours [5]. Since our present results and those of others do not suggest that the detection of direct and indirect markers of HPV infection would properly select individuals at risk of TC, serology might be the method of choice for the screening of OPC, because HPV-specific antibodies were detected long before the diagnosis of OPC [17].

In conclusion, our data provide further evidence of the etiological role of HR-HPV 16 in a substantial proportion of tonsillar tumours. The role of other HR-HPV types seems to be passive since we did not detect E6 mRNA and p16 protein expression in TCs positive for these HPV types. In tumourfree tonsillar tissues, the presence of HR-HPV types was rare and silent as evidenced by both direct and indirect markers of HPV infection. Our findings support the results reported by others and additionally show that active HPV infection in tumour-free tissues is even rarer. Therefore, the screening to identify persons at risk of TC will probably have to be based on multiple approaches.

Acknowledgements: This work was supported by the Ministry of Education, Youth and Sports of the Czech Republic within the National Sustainability Program II (Project BIOCEV-FAR) LQ1604 and by the project "BIOCEV" (CZ.1.05/1.1.00/02.0109).

\section{References}

[1] BERNARD HU, BURK RD, CHEN Z, VAN DOORSLAER $\mathrm{K}, \mathrm{ZUR}$ HAUSEN $\mathrm{H}$ et al. Classification of papillomaviruses (PVs) based on $189 \mathrm{PV}$ types and proposal of taxonomic amendments. Virology 2010; 401: 70-79. doi: 10.1016/j.virol.2010.02.002

[2] BREWSTER DH, BHATTI LA. Increasing incidence of squamous cell carcinoma of the anus in Scotland, 1975-2002. Br J Cancer 2006; 95: 87-90.
[3] DE SANJOSE S, CORTES X, MENDEZ C, PUIG-TINTORE L, TORNE A et al. Age at sexual initiation and number of sexual partners in the female Spanish population Results from the AFRODITA survey. Eur J Obstet Gynecol Reprod Biol 2008; 140: 234-240. doi: 10.1016/j.ejogrb.2008.04.005

[4] NASMAN A, ATTNER P, HAMMARSTEDT L, DU J, ERIKSSON M et al. Incidence of human papillomavirus (HPV) positive tonsillar carcinoma in Stockholm, Sweden: an epidemic of viral-induced carcinoma? Int J Cancer 2009; 125: 362-366. doi: 10.1002/ijc.24339

[5] ROTNAGLOVA E, TACHEZY R, SALAKOVA M, PROCHAZKA B, KOSL'ABOVA E et al. HPV involvement in tonsillar cancer: prognostic significance and clinically relevant markers. Int J Cancer 2011; 129: 101-110. doi: 10.1002/ ijc. 25889

[6] KREIMER AR, BHATIA RK, MESSEGUER AL, GONZALEZ $P$, HERRERO R et al. Oral human papillomavirus in healthy individuals: a systematic review of the literature. Sex Transm Dis 2010; 37: 386-391. doi: 10.1097/OLQ.0b013e3181c94a3b

[7] D'SOUZA G, KLUZ N, WENTZ A, YOUNGFELLOW RM, GRIFFIOEN A et al. Oral Human Papillomavirus (HPV) Infection among Unvaccinated High-Risk Young Adults. Cancers (Basel) 2014; 6: 1691-1704. doi: 10.3390/cancers6031691

[8] CHUNG CH, BAGHERI A, D’SOUZA G. Epidemiology of oral human papillomavirus infection. Oral Oncol 2014; 50: 364-369. doi: 10.1016/j.oraloncology.2013.09.003

[9] SMITH EM, RITCHIE JM, SUMMERSGILL KF, HOFFMAN HT, WANG DH et al. Human papillomavirus in oral exfoliated cells and risk of head and neck cancer. J Natl Cancer Inst 2004; 96: 449-455.

[10] TACHEZY R, KLOZAR J, RUBENSTEIN L, SMITH E, SALAKOVA $M$ et al. Demographic and risk factors in patients with head and neck tumors. J Med Virol 2009; 81: 878-887. doi: 10.1002/jmv.21470

[11] KOSLABOVA E, HAMSIKOVA E, SALAKOVA M, KLOZAR J, FOLTYNOVA E et al. Markers of HPV infection and survival in patients with head and neck tumors. Int J Cancer 2013; 133: 1832-1839. doi: 10.1002/ijc.28194

[12] BOTTALICO D, CHEN Z, DUNNE A, OSTOLOZA J, MCKINNEY S et al. The oral cavity contains abundant known and novel human papillomaviruses from the Betapapillomavirus and Gammapapillomavirus genera. J Infect Dis 2011; 204: 787-792. doi: 10.1093/infdis/jir383

[13] PAOLINI F, RIZZO C, SPERDUTI I, PICHI B, MAFERA $\mathrm{B}$ et al. Both mucosal and cutaneous papillomaviruses are in the oral cavity but only alpha genus seems to be associated with cancer. J Clin Virol 2013; 56: 72-76. doi: 10.1016/j. jcv.2012.09.016

[14] SABOL I, SMAHELOVA J, KLOZAR J, MRAVAK-STIPETIC M, GHEIT T et al. Beta-HPV types in patients with head and neck pathology and in healthy subjects. J Clin Virol 2016; 82: 159-165. doi: 10.1016/j.jcv.2016.07.019

[15] KOSKINEN WJ, CHEN RW, LEIVO I, MAKITIE A, BACK L et al. Prevalence and physical status of human papillomavirus in squamous cell carcinomas of the head and neck. Int J Cancer 2003; 107: 401-406. 
[16] LINDEL K, HELMKE B, SIMON C, WEBER KJ, DEBUS J et al. Cutaneous human papillomavirus in head and neck squamous cell carcinomas. Cancer Invest 2009; 27: 781-787. doi: 10.1080/07357900802653456

[17] KREIMER AR, JOHANSSON M, WATERBOER T, KAAKS R, CHANG-CLAUDE J et al. Evaluation of human papillomavirus antibodies and risk of subsequent head and neck cancer. J Clin Oncol 2013; 31: 2708-2715. doi: 10.1200/ JCO.2012.47.2738

[18] FRANCESCHI S, COMBES JD, DALSTEIN V, CAUDROY $\mathrm{S}$, CLIFFORD G et al. Deep brush-based cytology in tonsils resected for benign diseases. Int J Cancer 2015; 137: 29942999. doi: 10.1002/ijc. 29660

[19] SYRJANEN S. HPV infections and tonsillar carcinoma. J Clin Pathol 2004; 57: 449-455.

[20] CHEN R, SEHR P, WATERBOER T, LEIVO I, PAWLITA M et al. Presence of DNA of human papillomavirus 16 but no other types in tumor-free tonsillar tissue. J Clin Microbiol 2005; 43: 1408-1410. doi: 0.1128/JCM.43.3.1408-1410.2005

[21] MAMMAS IN, SOURVINOS G, MICHAEL C, SPANDIDOS DA. Human papilloma virus in hyperplastic tonsillar and adenoid tissues in children. Pediatr Infect Dis J 2006; 25 : 1158-1162. doi: 10.1097/01.inf.0000245094.15643.8c

[22] SISK J, SCHWEINFURTH JM, WANG XT, CHONG K. Presence of human papillomavirus DNA in tonsillectomy specimens. Laryngoscope 2006; 116: 1372-1374. doi: 10.1097/01. mlg.0000225973.21736.bc

[23] ERNSTER JA, SCIOTTO CG, O'BRIEN MM, ROBINSON LJ, WILLSON T. Prevalence of oncogenic human papillomavirus 16 and 18 in the palatine tonsils of the general adult population. Arch Otolaryngol Head Neck Surg 2009; 135: 554-557. doi: 10.1001/archoto.2009.49

[24] PALMER E, NEWCOMBE RG, GREEN AC, KELLY C, NOEL GO et al. Human papillomavirus infection is rare in nonmalignant tonsil tissue in the UK: implications for tonsil cancer precursor lesions. Int J Cancer 2014; 135: 2437-2443. doi: 10.1002/ijc.28886

[25] KLINGENBERG B, HAFKAMP HC, HAESEVOETS A, MANNI JJ, SLOOTWEG PJ et al. p16 INK4A overexpression is frequently detected in tumour-free tonsil tissue without association with HPV. Histopathology 2010; 56: 957967. doi: 10.1111/j.1365-2559.2010.03576.x

[26] SAIKI RK, SCHARF S, FALOONA F, MULLIS KB, HORN GT et al. Enzymatic amplification of beta-globin genomic sequences and restriction site analysis for diagnosis of sickle cell anemia. Science 1985; 230: 1350-1354.

[27] TACHEZY R, SMAHELOVA J, KASPIRKOVA J, SALAKOVA M. Human papillomavirus type-specific prevalence in the cervical cancer screening population of Czech women. PLoS One 2013; 8: e79156. doi: 10.1371/journal.pone.0079156

[28] FORSLUND O, ANTONSSON A, NORDIN P, STENQUIST B, HANSSON BG. A broad range of human papillomavirus types detected with a general PCR method suitable for analysis of cutaneous tumours and normal skin. J Gen Virol 1999; 80: 2437-2443. doi: 10.1099/0022-1317-80-9-2437

[29] FORSLUND O, LY H, HIGGINS G. Improved detection of cutaneous human papillomavirus DNA by single tube nested 'hanging droplet' PCR. J Virol Methods 2003; 110: 129-136.
[30] SMEETS SJ, HESSELINK AT, SPEEL EJ, HAESEVOETS A, SNIJDERS PJ et al. A novel algorithm for reliable detection of human papillomavirus in paraffin embedded head and neck cancer specimen. Int J Cancer 2007; 121: 2465-2472. doi: 10.1002/ijc.22980

[31] NAKAGAWA S, YOSHIKAWA H, YASUGI T, KIMURA M, KAWANA $\mathrm{K}$ et al. Ubiquitous presence of E6 and E7 transcripts in human papillomavirus-positive cervical carcinomas regardless of its type. J Med Virol 2000; 62: 251-258.

[32] BEGUM S, CAO D, GILLISON M, ZAHURAK M, WESTRA WH. Tissue distribution of human papillomavirus 16 DNA integration in patients with tonsillar carcinoma. Clin Cancer Res 2005; 11: 5694-5699. doi: 10.1158/1078-0432. CCR-05-0587

[33] D'SOUZA G, KREIMER AR, VISCIDI R, PAWLITA M, FAKHRY C et al. Case-control study of human papillomavirus and oropharyngeal cancer. N Engl J Med 2007; 356: 1944-1956. doi: 10.1056/NEJMoa065497

[34] D`SOUZA G, SUGAR E, RUBY W, GRAVITT P, GILLISON M. Analysis of the effect of DNA purification on detection of human papillomavirus in oral rinse samples by PCR. J Clin Microbiol 2005; 43: 5526-5535. doi: 10.1128/ JCM.43.11.5526-5535.2005

[35] NDIAYE C, MENA M, ALEMANY L, ARBYN M, CASTELLSAGUE $X$ et al. HPV DNA, E6/E7 mRNA, and p16INK4a detection in head and neck cancers: a systematic review and meta-analysis. Lancet Oncol 2014; 15: 1319-1331. doi: 10.1016/S1470-2045(14)70471-1

[36] SNIJDERS PJ, CROMME FV, VAN DEN BRULE AJ, SCHRIJNEMAKERS HF, SNOW GB et al. Prevalence and expression of human papillomavirus in tonsillar carcinomas, indicating a possible viral etiology. Int J Cancer 1992; 51: $845-850$.

[37] GHEIT T, LANDI S, GEMIGNANI F, SNIJDERS PJ, VACCARELLA $S$ et al. Development of a sensitive and specific assay combining multiplex PCR and DNA microarray primer extension to detect high-risk mucosal human papillomavirus types. J Clin Microbiol 2006; 44: 2025-2031. doi: 10.1128/ JCM.02305-05

[38] GHEIT T, BILLOUD G, DE KONING MN, GEMIGNANI F, FORSLUND $\mathrm{O}$ et al. Development of a sensitive and specific multiplex PCR method combined with DNA microarray primer extension to detect Betapapillomavirus types. J Clin Microbiol 2007; 45: 2537-2544. doi: 10.1128/JCM.00747-07

[39] SCHMITT M, DONDOG B, WATERBOER T, PAWLITA M, TOMMASINO M et al. Abundance of multiple high-risk human papillomavirus (HPV) infections found in cervical cells analyzed by use of an ultrasensitive HPV genotyping assay. J Clin Microbiol 2010;48: 143-149. doi: 10.1128/JCM.00991-09

[40] AGALLIU I, GAPSTUR S, CHEN Z, WANG T, ANDERSON RL et al. Associations of Oral alpha-, beta-, and gammaHuman Papillomavirus Types With Risk of Incident Head and Neck Cancer. JAMA Oncol 2016; doi: 10.1001/jamaoncol.2015.5504

[41] VIARISIO D, MULLER-DECKER K, ZANNA P, KLOZ U, AENGENEYNDT B et al. Novel ss-HPV49 Transgenic Mouse Model of Upper Digestive Tract Cancer. Cancer Res 2016; 76: 4216-25. doi: 10.1158/0008-5472.CAN-16-0370 
[42] HOLZINGER D, SCHMITT M, DYCKHOFF G, BENNER A, PAWLITA $M$ et al. Viral RNA patterns and high viral load reliably define oropharynx carcinomas with active HPV16 involvement. Cancer Res 2012; 72: 4993-5003. doi: 10.1158/0008-5472.CAN-11-3934

[43] VOJTECHOVAZ, SABOLI, SALAKOVA M, TUREKL, GREGA M et al. Analysis of the integration of human papillomaviruses in head and neck tumours in relation to patients' prognosis. Int J Cancer 2016; 138: 386-395. doi: 10.1002/ijc.2971

[44] HALEC G, ALEMANY L, LLOVERAS B, SCHMITT M, ALEJO $\mathrm{M}$ et al. Pathogenic role of the eight probably/possibly carcinogenic HPV types 26, 53, 66, 67, 68, 70, 73 and 82 in cervical cancer. J Pathol 2014; 234: 441-451. doi: 10.1002/ path. 4405
[45] RIETBERGEN MM, LEEMANS CR, BLOEMENA E, HEIDEMAN DA, BRAAKHUIS BJ et al. Increasing prevalence rates of HPV attributable oropharyngeal squamous cell carcinomas in the Netherlands as assessed by a validated test algorithm. Int J Cancer 2013; 132: 1565-1571. doi: 10.1002/ ijc. 27821

[46] BABOCI L, BOSCOLO-RIZZO P, HOLZINGER D, BERTORELLE R, BIASINI L et al. Evidence of the causal role of human papillomavirus type 58 in an oropharyngeal carcinoma. Virol J 2013; 10: 334. doi: 10.1186/1743-422X-10-334

[47] GEISLER SA, OLSHAN AF, WEISSLER MC, CAI J, FUNKHOUSER WK et al. p16 and p53 Protein expression as prognostic indicators of survival and disease recurrence from head and neck cancer. Clin Cancer Res 2002; 8: 3445-3453. 